\title{
Pembelajaran Online di Tengah Pandemi Covid-19
}

\author{
Firman $^{1}$, Sari Rahayu Rahman ${ }^{1}$ \\ 1. Prodi Pendidikan Biologi, FKIP, Universitas Sulawesi Barat \\ email: firman@unsulbar.ac.id
}

\begin{abstract}
Abstrak
Penelitian ini merupakan penelitian kualitatif yang bertujuan untuk memperoleh gambaran pelaksanaan pembelajaran online di Prodi Pendidikan Biologi Fakultas Keguruan dan Ilmu Pendidikan (FKIP) Universitas Sulawesi Barat (Unsulbar) sebagai upaya menekan penyebaran covid-19 di lingkungan kampus. Subjek penelitian adalah mahasiswa Prodi Pendidikan Biologi. Data dikumpulkan dengan wawancara melalui telepon. Analisis data dilakukan menggunakan teknik analisis interaktif Miles \& Huberman. Hasil penelitian menunjukkan bahwa: (1) mahasiswa telah memiliki fasilitas-fasilitas dasar yang dibutuhkan untuk mengikuti pembelajaran online; (2) pembelajaran online memiliki fleksibilitas dalam pelaksanaannya dan mampu mendorong munculnya kemandirian belajar dan motivasi untuk lebih aktif dalam belajar; dan (3) pembelajaran jarak jauh mendorong munculnya perilaku social distancing dan meminimalisir munculnya keramaian mahasiswa sehingga dianggap dapat mengurangi potensi penyebaran Covid-19 di lingkungan kampus.
\end{abstract}

Kata kunci: Pembelajaran online, Covid-19, Social distancing

\section{PENDAHULUAN}

Sejak merebaknya pandemi yang disebabkan oleh virus Corona di Indonesia, banyak cara yang dilakukan oleh pemerintah untuk mencegah penyebarannya. Salah satunya adalah melalui surat edaran Kementrian Pendidikan dan Kebudayaan (Kemendikbud) Direktorat Pendidikan Tinggi No 1 tahun 2020 tentang pencegahan penyebaran Corona Virus Disease (Covid-19) di perguruan tinggi. Melalui surat edaran teresebut pihak Kemendikbud memberikan instruksi kepada perguruan tinggi untuk menyelenggarakan pembelajaran jarak jauh dan menyarankan mahasiswa untuk belajar dari rumah masing-masing.

Banyak perguruan tinggi dengan sigap menanggapi instruksi tersebut, salah satunya Universitas Indonesia yang menerbitkan surat edaran tentang kewaspadaan dan pencegahan penyebaran infeksi Covid-19 di lingkungan UI. Di dalam surat tersebut dimuat 10 poin yang salah satunya berupa himbauan untuk mengubah pembelajaran tatap muka menjadi pembelajaran jarak jauh (Yandwiputra, 2020). Setidaknya terdapat 65 perguruan tinggi di Indonsesia yang menyelenggarakan pembelajaran dari rumah untuk mencegah penyebaran Covid-19 (CNNIndonesia, 2020).

Sebagai usaha pencegahan penyebaran Covid-19, WHO merekomendasikan untuk menghentikan sementara kegiatan-kegiatan yang berpotensi menimbulkan kerumunan massa. Untuk itu pembelajaran konvensional yang mengumpulkan banyak mahasiswa dalam satu ruangan perlu ditinjau ulang pelaksanaannya. Pembelajaran harus dilaksanakan dengan skenario yang mampu meminimalisir kontak fisik antara mahasiswa dengan mahasiswa lain, ataupun antara mahasiswa dengan dosen. Menurut Milman (2015) penggunaan teknologi digital memungkinkan mahasiswa dan dosen berada di tempat yang berbeda selama proses pembelajaran. 
Salah satu bentuk pembelajaran alternatif yang dapat dilaksasnakan selama masa darurat Covid-19 adalah pembelajaran secara online. Menurut Moore, Dickson-Deane, \& Galyen (2011) Pembelajaran online merupakan pembelajaran yang menggunakan jaringan internet dengan aksesibilitas, konektivitas, fleksibilitas, dan kemampuan untuk memunculkan berbagai jenis interaksi pembelajaran. Penelitian yang dikakukan oleh Zhang et al., (2004) menunjukkan bahwa penggunaan internet dan teknologi multimedia mampu merombak cara penyampaian pengetahuan dan dapat menjadi alternatif pembelajaran yang dilaksanakan dalam kelas tradisional.

Pembelajaran online pada pelaksanaannya membutuhkan dukungan perangkat-perangkat mobile seperti telepon pintar, tablet dan laptop yang dapat digunakan untuk mengakses informasi dimana saja dan kapan saja (Gikas \& Grant, 2013). Penggunaan teknologi mobile memiliki kontribusi besar di dunia pendidikan, termasuk di dalamnya adalah pencapaian tujuan pembelajaran jarak jauh (Korucu \& Alkan, 2011). Berbagai media juga dapat digunakan untuk mendukung pelaksanaan pembelajaran secara online. Misalnya kelas-kelas virtual menggunakan layanan Google Classroom, Edmodo, dan Schoology (Enriquez, 2014; Sicat, 2015; Iftakhar, 2016), dan applikasi pesan instan seperti WhatsApp (So, 2016). Pembelajaran secara online bahkan dapat dilakukan melalui media social seperti Facebook dan Instagram (Kumar \& Nanda, 2018).

\section{Metode}

Penelitian ini merupakan penelitian kualitatif yang bertujuan untuk memperoleh gambaran pembelajaran online yang dilaksanakan di Prodi Pendidikan Biologi FKIP Unsulbar sebagai usaha untuk menekan penyebaran Covid-19 di lingkungan kampus. Pembelajaran online yang dimaksud dalam penelitian ini adalah pembelajaran yang menggunakan media-media pembelajaran yang dapat diakeses menggunakan layanan internet. Penelitian dilakukan dengan terlebih dahulu mengadakan survey kepada mahasiswa mengenai penerapan pembelajaran online. Survey dilaksanakan menggunakan google form yang tautannya disebarkan melalui applikasi WhatsApp. Terdapat 95 mahasiswa yang memberikan tanggapan terhadap survey yang dilakukan. Hasil survey kemudian dikelompokkan kedalam tiga kategori respon mahasiswa: (1) Setuju dengan penerapan pembelajaran online; (2) Tidak setuju dengan penerapan pembelajaran online; (3) Ragu dengan pelaksanaan pembelajaran online.

Subjek penelitian adalah mahasiswa Prodi Pendidikan Biologi yang aktif mengikuti pembelajaran online, dan dipilih berdasarkan kategori respon mahasiswa yang didapatkan dari hasil survey. Terdapat total 9 subjek, 3 mahasiswa angkatan 2017, 3 mahasiswa angkatan 2018, dan 3 mahasiswa angkatan 2019, 4 diantaranya berjenis kelamin laki-laki dan 5 perempuan. Pengumpulan data dilakukan melalui wawancara via telpon. Aspek-aspek yang ditanyakan selama wawancara adalah: (1) Fasilitas yang dimiliki mahasiswa untuk mendukung pelaksanaan pembelajaran online; (2) Tanggapan mahasiswa mengenai efektivitas pembelajaran online; (3) Penerapan pembelajaran online dalam menekan penyebaran Covid-19 di lingkungan kampus. Analisis data penelitian dilakukan menggunakan model analisis Miles \& Huberman (1994) yang terdiri dari tiga tahapan, yaitu reduksi data, display data, serta penarikan dan verifikasi kesimpulan.

\section{Hasil dan Pembahasan}


1. Mahasiswa memiliki fasilitas yang memadai untuk melaksanakan pembelajaran online

Meningkatnya pengguna internet di Indonesia sangat dipengaruhi oleh pesatnya perkembangan Teknologi Informasi dan Komunikasi (TIK). Pada tahun 2018 sebanyak 62,41\% penduduk Indonesia telah memiliki telepon selular dan 20,05\% rumah tangga yang memiliki komputer (BPS, 2019). Data ini sangat relevan dengan hasil penelitian yang menunjukkan bahwa meskipun ada mahasiswa yang belum memiliki laptop, tapi hampir semua mahasiswa Prodi Pendidikan Biologi FKIP Unusulbar telah memiliki telepon pintar. Hasil survey yang dilaksanakan pada awal penelitian menunjukkan bahwa dari total 95 responden, 54 menyatakan memiliki laptop dan telepon pintar, sementara 41 sisanya menyatakan hanya memiliki telepon pintar.

Banyak penelitian yang menyelidiki penggunaan gawai seperti laptop dan telepon pintar dalam pembelajaran. Kemampuan laptop dan telepon pintar untuk mengakses internet memungkinkan mahasiswa untuk mengikuti perkuliahan yang dilaksanakan dalam bentuk konferensi video maupun yang dilaksanakan dalam kelas-kelas virtual menggunakan layanan applikasi-applikasi pembelajaran yang tersedia secara online (Kay \& Lauricella, 2011; Gikas \& Grant, 2013; Chan, Walker, \& Gleaves, 2015; Gökçearslan, Mumcu, Haşlaman, \& Çevik, 2016). Dimensi laptop dan telepon pintar yang ergonomis memberikan jaminan mobilitas yang memungkinkan mahasiswa untuk mengikuti perkuliahan dari mana saja. Fitur penyimpanan yang ditawarkan oleh laptop dan telepon pintar juga memberikan ruang bagi mahasiswa untuk menyimpan bahan ajar yang diberikan oleh dosen sehingga mereka dapat mengakses ulang bahan ajar tersebut sewaktu-waktu.

Sayangnya pembelajaran online juga memiliki tantangan tersendiri. Salah satunya adalah ketersediaan layanan internet. Data penelitian menunjukkan bahwa sebagian besar mahasiswa mengakses internet menggunakan layanan selular, sementara sebagian kecilnya menggnakan layanan WiFi. Menurut data BPS (2019) per tahun 2018 terdapat 66,13\% wilayah pulau Sulawesi dengan layanan seluler dengan kekuatan penerimaan sinyal kuat, 27,22\% wilayah dengan kekuatan penerimaan sinyal lemah, dan $6,64 \%$ wilayah yang masih belum dijangkau layanan seluler. Pada saat kebijakan belajar dari rumah untuk menekan penyebaran Covid-19 diberlakukan di Unsulbar, banyak mahasiswa yang memilih untuk pulang kampung. Mereka mengaku kesulitan untuk mengikuti pembelajaran secara online karena tidak semua wilayah kampung mereka mendapatkan sinyal seluler, jikapun ada, sinyal yang didapat sangat lemah. Hal ini membuat mahasiswa terkadang terlambat mendapatkan informasi perkuliahan dan mengumpulkan tugas kuliah.

Selain ketersediaan layanan internet, tantangan lain yang harus dihadapi adalah kendala biaya. mahasiswa menyatakan bahwa untuk mengikuti pembelajaran secara online, mereka harus mengeluarkan biaya lebih untuk membeli kuota data internet. Menurut mahasiwa, pembelajaran yang dilaksanakan dalam bentuk konferensi video menghabiskan kuota yang sangat banyak, sementara diskusi online melalui applikasi pesan instan tidak membutuhkan banyak kuota. Dikutip dari CNNIndonesia (2020) konsumsi data untuk video konferensi menggunakan applikasi Zoom dengan kualitas video 720p selama satu jam menghabiskan data sebesar $540 \mathrm{MB}$. Hasil survey peneliti di beberapa situs resmi provider seluler menunjukkan harga kuota data sebesar 1 GB berkisar antara Rp. 20.000 hingga Rp. 50.000. Jika diasumsikan bahwa rata-rata mahasiswa memprogramkan 8 mata kuliah tiap semester dan masing-masing mata kuliah melaksanakan kuliah online menggunakan appllikasi konferensi video selama satu 
jam setiap minggu, maka mahasiswa harus menghabiskan dana antara Rp.80.000 hingga Rp. 200.000 per minggu, tergantung provider seluler yang digunakan.

Walaupun penggunaan gawai dapat menunjang proses pembelajaran online, namun ada beberapa hal yang harus diperhatikan, termasuk kemungkinan adanya dampak negatif penyalahgunaan dan penggunaan gawai yang berlebihan. Mahasiswa mengakui bahwa selain untuk pembelajaran, mereka juga menggunakan telepon pintar untuk mengakses media sosial. Lau (2017) menyatakan bahwa media sosial telah memasuki kehidupan golongan dewasa muda. Mahasiswa menggunakan media sosial untuk mengekspresikan diri, opini dan membangun hubungan pertemanan (Kim, Wang, \& Oh, 2016). Sayangnya, beberpa penelitian terbaru menunjukkan adanya indikasi kecanduan gadget akibat penggunaan gadget berlebihan (Waslh, White \& Young, 2007). Hal ini menimbulkan kekhawatiran akan efek negatif penggunaan gadget dan media sosial seperti kemungkinan terpapar informasi yang salah dan tidak perhatian selama belajar akibat bermain media sosial (Siddiqui \& Singh, 2016). Selain itu, orang yang kecanduan gadget cenderung memiliki masalah sosial dan akademik (Kwon et al., 2013)

\section{Efektivitas Pembelajaran Online}

Pembelajaran online yang diberlakukan di Prodi Pendidikan Biologi FKIP Unsulbar sebagai usaha untuk menekan penyebaran Covid-19 dilaksanakan menggunakan applikasiapplikasi pembelajaran serta layanan-layanan kelas virtual yang dapat diakses melalui web menggunakan jaringan internet. Secara umum, mahasiswa merasa puas mengenai fleksibilitas pelaksanaan perkuliahan. Mahasiswa tidak tertekan oleh waktu karena mereka dapat mengatur sendiri jadwal dan tempat dimana mereka ingin mengikuti perkuliahan. Melalui pembelajaran secara online, dosen memberikan kuliah melalui kelas-kelas virtual yang dapat diakses dimanapun dan kapanpun. Hal ini membuat mahasiswa dapat secara bebas memilih mana mata kuliah yang diikuti dan tugas yang harus dikerjakan lebih dahulu. Hasil penelitian Sun et al., (2008) menunjukkan bahwa fleksibilitas waktu, lokasi, dan metode pembelajaran online mempengaruhi kepuasan mahasiswa terhadap pembelajaran.

Terdapat satu temuan menarik dalam penelitian ini. Mahasiswa merasa lebih nyaman untuk bertanya dan mengemukakan pendapat dalam forum perkuliahan yang dilaksanakan secara online. Belajar dari rumah membuat mereka tidak merasakan tekanan sebaya yang biasa mereka rasakan ketika belajar bersama teman di dalam perkuliahan yang dilakasanakan secara tatap muka. Ketidakhadiran dosen secara fisik juga membuat mereka tidak merasa canggung dalam mengemukakan pendapat. Menurut Sun et al., (2008) ketiadaaan penghambat fisik serta batasan ruang dan waktu membuat mahasiswa lebih mudah dalam berkomunikasi. Selain itu pembelajaran secara online menghilangkan perasaan canggung sehingga mahasiswa dapat mengekpresikan fikirannya dan bertanya secara bebas.

Pembelajaran jarak jauh secara online juga mampu menumbuhkan kemandirian belajar mahasiswa. Belajar tanpa bimbingan langsung dari dosen membuat mahasiswa secara mandiri mencari informasi mengenai materi kuliah dan tugas-tugas yang diberikan kepada mereka. Beberapa aktivitas yang dilakukan adalah membaca buku referensi, artikel online, jurnal-jurnal ilmiah, atau berdiskusi dengan rekan sebaya melalui applikasi-applikasi pesan instan. Kuo et al., (2014) menyatakan bahwa pembelajaran secara online lebih bersifat student centered sehingga mampu memunculkan tanggung jawab dan otonomi mahasiswa dalam belajar. Belajar 
online menuntut mahasiswa untuk mempersiapkan sendiri pembelajarannya, mengatur dan mengevaluasi serta secara simultan mempertahankan motivasi belajarnya (Sun, 2014).

Pembelajaran yang dilaksanakan secara online juga memiliki tantangan tersendiri. Lokasi dosen dan mahasiswa yang terpisah saat melaksanakan pembelajaran membuat dosen tidak bisa memantau secara langsung aktivitas mahasiswa selama proses perkuliahan. Tidak ada jaminan bahwa mahasiswa benar-benar memperhatikan penjelasan yang diberikan oleh dosen. Szpunar, Moulton, \& Schacter, (2013) menyatakan bahwa mahasiswa menghayal lebih sering pada perkuliahan online dibandingkan dengan perkuliahan tatap muka. Untuk itu Khan (2012) menyarankan bahwa perkuliahan online harus dilaksanakan dalam waktu yang tidak lama karena mahasiswa kesulitan mempertahankan konsentrasi jika perkuliahan secara online dilaksanakan lebih dari satu jam.

Data penelitian juga menunjukkan bahwa banyak mahasiswa yang kesulitan dalam memahami materi kuliah yang diberikan secara online. Materi kuliah yang kebanyakan berupa bahan bacaan tidak bisa dipahami secara menyeluruh oleh mahasiswa. Mahasiswa beranggapan bahwa mambaca materi dan mengerjakan tugas saja tidak cukup, mereka membutuhkan penjelasan langsung secara verbal dari dosen mengenai beberapa materi yang sifatnya kompleks. Komunikasi dengan dosen melalui applikasi pesan instan ataupun pada kolom diskusi yang disediakan oleh applikasi kelas-kelas virtual tidak mampu memberikan penjelasan menyeluruh mengenai materi yang sedang dibahas. Garrison \& Cleveland-Innes (2005) melakukan penelitian dengan merekayasa keterlibatan dosen dalam perkuliahan secara online. Pada kelas dimana keterlibatan dosennya sangat sedikit, tidak menunjukkan adanya pembelajaran yang mendalam dan bermakna. Interaksi dengan dosen menjadi sangat penting dalam pembelajaran online karena mampu mengurangi jarak psikologis yang pada gilirannya akan menuntun pada pembelajaran yang lebih baik (Swan, 2002).

\section{Pembelajaran Online Menekan Penyebaran Covid-19 di Kampus}

Covid-19 merupakan penyakit dengan tingkat penyebaran yang tergolong cepat. Penyakit ini disebabkan oleh virus Corona yang secara khusus menyerang sistem pernafasan manusia (Rothan \& Byrareddy, 2020). Pengendalian penyakit menular dapat dilakukan dengan meminimalisir kontak antara orang yang terinfeksi dengan orang-orang yang rentan ditulari (Caley, Philp, \& McCracken, 2008). Menjaga jarak untuk mengurangi kontak fisik yang berpotensi menularkan penyakit dikenal dengan istilah social distancing (Bell et al., 2006).

Sebagai usaha untuk mengurangi penyebaran Covid-19 di lingkungan kampus, Unsulbar membuat kebijakan untuk melaksanakan pembelajaran dari rumah. Pembelajaran ini dilakukan menggunakan internet sehingga memungkinkan dosen dan mahasiswa untuk berada di tempat yang berbeda selama proses pembelajaran. dosen dapat membuat materi ajar yang dapat diakses oleh mahasiswa secara online dari mana saja dan kapan saja. Menurut Bell et al., (2017) pembelajaran yang dilaksankan menggunakan teknologi internet memungkinkan adanya interaksi melalui web, dimana dosen dan mahasiswa berada di tempat yang benar-benar terpisah (Arzayeva, et al., 2015). Lokasi mahasiswa dan dosen yang terpisah selama pembelajaran meminimalisir kemungkinan terjadinya kontak fisik sehingga pada gilirannya mampu mendorong munculnya perilaku social distancing. Menurut Stein (2020) melaksanakan social distancing dianggap sebagai sebuah tindakan yang perlu guna menekan penyebaran Covid-19. 
Penerapan pembelajaran online memungkinkan mahasiswa untuk mengikuti perkuliahan dari rumah masing-masing. Mereka dapat mengakses bahan ajar dan mengirimkan tugas yang diberikan oleh dosen tanpa harus datang ke kampus. Hal ini dapat mengurangi potensi munculnya kerumunan di kampus seperti yang mungkin terjadi jika pembelajaran secara tatap muka di dalam kelas tetap dilaksanakan. WHO (2020) mengemukakan bahwa membatasi perkumpulan massa dapat mengurangi potensi penyebaran Covid-19.

Sayangnya, di daerah-daerah yang tidak memiliki konektivitas jaringan internet yang baik, pembelajaran online menunjukkan kecenderungan yang berbeda. Untuk dapat mengikuti pembelajaran online, mahasiswa yang tinggal di wilayah yang tidak dijangkau jaringan internet harus menuju area-area tertentu seperti perbukitan atau pusat kecamatan dimana jaringan internet tersedia. Hal ini akan menimbulkan potensi keramaian dan justru memunculkan kemungkinan penyebaran Covid-19 di wilayah tersebut.

\section{Kesimpulan}

Sebagai usaha untuk menekan penyebaran Covid-19 di lingkungan kampus, maka Prodi Pendidikan Biologi FKIP Unsulbar melaksanakan pembelajaran online sebagai alternatif pembelajaran konvensional. Melalui penelitian ini kita dapat melihat bahwa secara umum mahasiswa telah memiliki fasilitas-fasilitas dasar yang dibutuhkan untuk mengikuti pembelajaran online. Meski demikian, terdapat beberapa hal yang harus diperhatikan, termasuk didalamnya ketersediaan layanan internet dan biaya tambahan yang harus dikeluarkan oleh mahasiswa.

Pembelajaran online mendapat tanggapan yang sangat baik dari mahasiswa terutama mengenai fleksibilitas pelaksanaannya. Metode pembelajaran ini juga mampu memicu munculnya kemandirian belajar dan mendorong mahasiswa untuk lebih aktif dalam perkuliahan. Sayangnya, interaksi dalam pembelajaran online memiliki batasan sehingga tidak memungkinkan dosen untuk memantau secara langsung aktivitas mahasiswa selama perkuliahan. Mahasiswa juga kesulitan memahami bahan ajar yang disampaiakan secara online. Komunikasi antara dosen dengan mahasiswa yang terbatas melalui applikasi pesan instan ataupun melalui kelas-kelas virtual dirasa tidak cukup oleh mahasiswa.

Pelaksanaan pembelajaran online memungkinkan mahasiswa untuk mengikuti perkuliahan dari rumah masing-masing. Hal ini mendorong munculnya perilaku social distancing dan meminimalisir kemungkinan munculnya kerumunan mahsiswa di kampus. Dua hal ini merupakan langkah-langkah yang direkomendasikan WHO dalam menekan penyebaran Covid19. Meski demikian, pembelajaran online di daerah-daerah yang tidak dijangkau jaringan internet harus diawasi karena berpotensi memunculkan kerumunan di area-area tertentu yang justru meningkatkan kemungkinan penyebaran Covid-19.

\section{Referensi}

Arzayeva, M., Rakhimzhanov, K., Abdrahmanova, A., \& Umitkaliev, U. (2015). Special aspects of distance learning in educational system. Anthropologist, 22(3), 449-454. https://doi.org/10.1080/09720073.2015.11891900 
Bell, D., Nicoll, A., Fukuda, K., Horby, P., Monto, A., Hayden, F., ... Van Tam, J. (2006). Nonpharmaceutical interventions for pandemic influenza, national and community measures. Emerging Infectious Diseases. https://doi.org/10.3201/eid1201.051371

Bell, S., Douce, C., Caeiro, S., Teixeira, A., Martín-Aranda, R., \& Otto, D. (2017). Sustainability and distance learning: a diverse European experience? Open Learning, 32(2), 95-102. https://doi.org/10.1080/02680513.2017.1319638

Caley, P., Philp, D. J., \& McCracken, K. (2008). Quantifying social distancing arising from pandemic influenza. Journal of the Royal Society Interface. https://doi.org/10.1098/rsif.2007.1197

Chan, N. N., Walker, C., \& Gleaves, A. (2015). An exploration of students' lived experiences of using smartphones in diverse learning contexts using a hermeneutic phenomenological approach. Computers and Education. https://doi.org/10.1016/j.compedu.2014.11.001

CNNIndonesia. (n.d.-a). 4 Aplikasi Video Conference yang Irit dan Boros Data. Retrieved from https://www.cnnindonesia.com/teknologi/20200330191529-185-488422/4-aplikasivideo-conference-yang-irit-dan-boros-data

CNNIndonesia. (n.d.-b). 65 Kampus Kuliah dari Rumah, Sultan Yogya Ragukan Efektivitas. Retrieved from https://www.cnnindonesia.com/nasional/20200316110707-20483756/65-kampus-kuliah-dari-rumah-sultan-yogya-ragukan-efektivitas

Enriquez, M. A. S. (2014). Students 'Perceptions on the Effectiveness of the Use of Edmodo as a Supplementary Tool for Learning. DLSU Research Congress. https://doi.org/10.1017/CBO9781107415324.004

Garrison, D. R., \& Cleveland-Innes, M. (2005). in Online Learning : Interaction Is Not Enough. American Journal of Distance Education. https://doi.org/10.1207/s15389286ajde1903

Gikas, J., \& Grant, M. M. (2013). Mobile computing devices in higher education: Student perspectives on learning with cellphones, smartphones \& social media. Internet and Higher Education. https://doi.org/10.1016/j.iheduc.2013.06.002

Gökçearslan, Ş., Mumcu, F. K., Haşlaman, T., \& Çevik, Y. D. (2016). Modelling smartphone addiction: The role of smartphone usage, self-regulation, general self-efficacy and cyberloafing in university students. Computers in Human Behavior. https://doi.org/10.1016/j.chb.2016.05.091

Iftakhar, S. (2016). GOOGLE CLASSROOM: WHAT WORKS AND HOW? Journal of Education and Social Sciences.

Kay, R. H., \& Lauricella, S. (2011). Exploring the Benefits and Challenges of Using Laptop Computers in Higher Education Classrooms: A Formative Analysis. Canadian Journal of Learning and Technology / La Revue Canadienne de l'apprentissage et de La Technologie. https://doi.org/10.21432/t2s598 
Kim, Y., Wang, Y., \& Oh, J. (2016). Digital Media Use and Social Engagement: How Social Media and Smartphone Use Influence Social Activities of College Students. Cyberpsychology, Behavior, and Social Networking. https://doi.org/10.1089/cyber.2015.0408

Korucu, A. T., \& Alkan, A. (2011). Differences between m-learning (mobile learning) and elearning, basic terminology and usage of m-learning in education. Procedia - Social and Behavioral Sciences. https://doi.org/10.1016/j.sbspro.2011.04.029

Kumar, V., \& Nanda, P. (2018). Social Media in Higher Education. International Journal of Information and Communication Technology Education. https://doi.org/10.4018/ijicte.2019010107

Kuo, Y. C., Walker, A. E., Schroder, K. E. E., \& Belland, B. R. (2014). Interaction, Internet self-efficacy, and self-regulated learning as predictors of student satisfaction in online education courses. Internet and Higher Education. https://doi.org/10.1016/j.iheduc.2013.10.001

Kwon, M., Lee, J. Y., Won, W. Y., Park, J. W., Min, J. A., Hahn, C., ... Kim, D. J. (2013). Development and Validation of a Smartphone Addiction Scale (SAS). PLoS ONE. https://doi.org/10.1371/journal.pone.0056936

Lau, W. W. F. (2017). Effects of social media usage and social media multitasking on the academic performance of university students. Computers in Human Behavior. https://doi.org/10.1016/j.chb.2016.11.043

Miles, M. B., \& Huberman, M. (1994). Qualitative Data Analysis Second Edition. SAGE Publications.

Milman, N. B. (2015). Distance Education. In International Encyclopedia of the Social \& Behavioral Sciences: Second Edition. https://doi.org/10.1016/B978-0-08-0970868.92001-4

Moore, J. L., Dickson-Deane, C., \& Galyen, K. (2011). E-Learning, online learning, and distance learning environments: Are they the same? Internet and Higher Education. https://doi.org/10.1016/j.iheduc.2010.10.001

Rothan, H. A., \& Byrareddy, S. N. (2020). The epidemiology and pathogenesis of coronavirus disease (COVID-19) outbreak. Journal of Autoimmunity. https://doi.org/10.1016/j.jaut.2020.102433

Salman Khan. (2012). The One World Schoolhouse. In Hachette Book Group. https://doi.org/10.1111/edth. 12072

Sicat, A. S. (2015). Enhancing College Students' Proficiency in Business Writing Via Schoology. International Journal of Education and Research. 
Siddiqui, S., \& Singh, T. (2016). Social Media its Impact with Positive and Negative Aspects. International Journal of Computer Applications Technology and Research. https://doi.org/10.7753/ijcatr0502.1006

So, S. (2016). Mobile instant messaging support for teaching and learning in higher education. Internet and Higher Education. https://doi.org/10.1016/j.iheduc.2016.06.001

Stein, R. (2020). COVID-19 and Rationally Layered Social Distancing . International Journal of Clinical Practice. https://doi.org/10.1111/ijcp.13501

Sun, P. C., Tsai, R. J., Finger, G., Chen, Y. Y., \& Yeh, D. (2008). What drives a successful eLearning? An empirical investigation of the critical factors influencing learner satisfaction. Computers and Education. https://doi.org/10.1016/j.compedu.2006.11.007

Sun, S. Y. H. (2014). Learner perspectives on fully online language learning. Distance Education. https://doi.org/10.1080/01587919.2014.891428

Swan, K. (2002). Building Learning Communities in Online Courses: the importance of interaction. Education, Communication \& Information. https://doi.org/10.1080/1463631022000005016

Szpunar, K. K., Moulton, S. T., \& Schacter, D. L. (2013). Mind wandering and education: From the classroom to online learning. Frontiers in Psychology. https://doi.org/10.3389/fpsyg.2013.00495

WHO. (n.d.). Points of entry and mass gatherings. Retrieved March 28, 2020, from https://www.who.int/emergencies/diseases/novel-coronavirus-2019/technicalguidance/points-of-entry-and-mass-gatherings

Yandwiputra, A. R. (n.d.). Kuliah Jarak Jauh karena Virus Corona, UI: Bukan Lockdown. Retrieved from https://metro.tempo.co/read/1319537/kuliah-jarak-jauh-karena-viruscorona-ui-bukan-lockdown

Zhang, D., Zhao, J. L., Zhou, L., \& Nunamaker, J. F. (2004). Can e-learning replace classroom learning? Communications of the ACM. https://doi.org/10.1145/986213.986216 